\title{
Effect of ocean acidification on cyanobacteria in the subtropical North Atlantic
}

\author{
M. W. Lomas ${ }^{1, *}$, B. M. Hopkinson ${ }^{2,3, * *}$, J. L. $\operatorname{Losh}^{2, * *}$ D. E. Ryan ${ }^{2, * *}$, D. L. Shi ${ }^{2,4, * *}$, \\ Y. Xu ${ }^{2, * *}$ F. M. M. Morel ${ }^{2}$ \\ ${ }^{1}$ Bermuda Institute of Ocean Sciences, St. George's GE01, Bermuda \\ ${ }^{2}$ Department of Geosciences, Princeton University, Princeton, New Jersey 08544, USA \\ ${ }^{3}$ Present address: Department of Marine Sciences, University of Georgia, Athens, Georgia 30602, USA \\ ${ }^{4}$ Present address: State Key Laboratory of Marine Environmental Science, College of the Environment and Ecology, \\ Xiamen University, Xiamen 361005, PR China
}

\begin{abstract}
Cyanobacteria make significant contributions to global carbon and nitrogen cycling, particularly in the oligotrophic subtropical and tropical gyres. The present study examined short-term (days) physiological and acclimation responses of natural cyanobacterial populations to changes in $\mathrm{pH} / \mathrm{pCO}_{2}$ spanning the last glacial minimum, $8.4 / \sim 150 \mathrm{ppm}$, to projected year 2100 values of $\sim 7.8 / \sim 800 \mathrm{ppm}$. Fe- and P-replete colonies of Trichodesmium increased $\mathrm{N}_{2}$-fixation rates (nmol $\mathrm{N}_{\text {colony }}{ }^{-1} \mathrm{~h}^{-1}$ ) at $\mathrm{pH} 7.8$ by $54 \%$ (range 6 to $156 \%$ ) over ambient $\mathrm{pH} / \mathrm{pCO}_{2}$ conditions, while $\mathrm{N}_{2}$ fixation at $\mathrm{pH} / \mathrm{pCO}_{2} 8.4$ was $21 \%$ (range 6 to $65 \%$ ) lower than at ambient $\mathrm{pH} / \mathrm{pCO}_{2}$; a similar pattern was observed when the rates were normalized to colony $\mathrm{C}$. C-fixation rates were on average $13 \%$ (range -72 to $112 \%$ ) greater at low $\mathrm{pH}$ than at ambient $\mathrm{pH}$ and $37 \%$ ( -53 to $23 \%$ ) greater than at high $\mathrm{pH}$. Whole community assemblages dominated by Prochlorococcus and Synechococcus (47 to $95 \%$ of autotrophic biomass), whether nutrient-replete or P-limited, did not show a clear response of $\mathrm{C}$-fixation rates to changes in $\mathrm{pH} / \mathrm{pCO}_{2}$. Comparison of initial and final C-fixation responses across $\mathrm{pH} / \mathrm{pCO}_{2}$ treatments suggests rapid acclimation of cellular physiology to new $\mathrm{pH} / \mathrm{pCO}_{2}$ conditions. Changes in cell size and pigment content for Prochlorococcus and Synechococcus were minor and did not vary in a consistent manner with changes in $\mathrm{pH} / \mathrm{pCO}_{2}$. These results for natural populations of all 3 cyanobacteria concur with previous research and suggest that one important response to changes in ocean $\mathrm{pH}$ and $\mathrm{pCO}_{2}$ might be an increase in $\mathrm{N}_{2}$ and $\mathrm{C}$ fixation by Trichodesmium under nutrient-replete conditions. The response of single-cell cyanobacteria to changes in $\mathrm{pH} / \mathrm{pCO}_{2}$ will likely be indirect and controlled by the response to other variables, such as nutrients.
\end{abstract}

\footnotetext{
*Email: michael.lomas@bios.edu

** These authors contributed equally to the design and execution of the experiments and are listed in alphabetical order
}

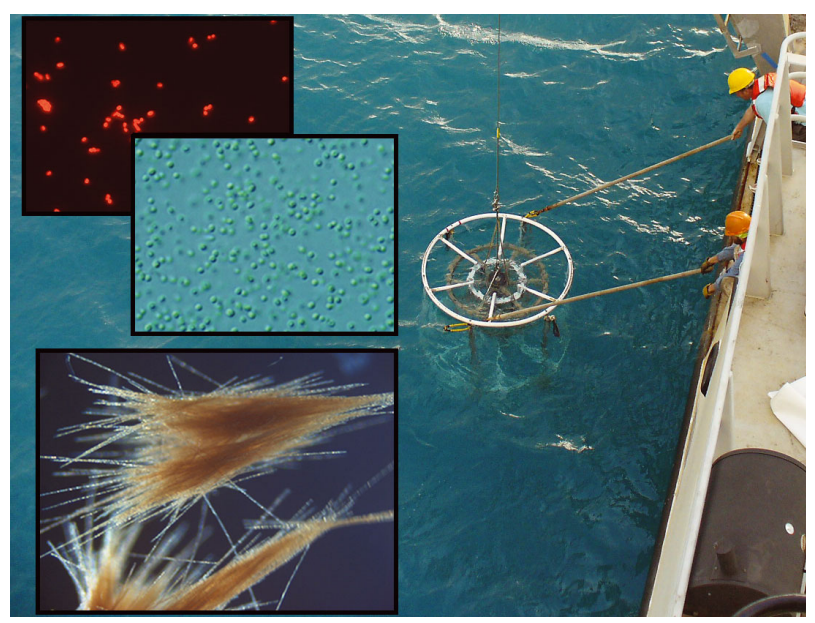

At sea ocean acidification experiments show contrasting responses between dominant unicellular and colonial natural cyanobacteria populations. Insets (top to bottom): Synechococcus (epifluorescence microscopy), Prochlorococcus (brightfield microscopy) and Trichodesmium (bright-field microscopy)

Photos: S. Jaeger and M. Lomas

KEY WORDS: Cyanobacteria $\cdot$ North Atlantic $\cdot$ Sargasso Sea $\cdot$ Acidification $\cdot$ Nitrogen fixation $\cdot$ Photosynthesis Resale or republication not permitted without written consent of the publisher

\section{INTRODUCTION}

Marine cyanobacteria, both unicellular Prochlorococcus and Synechococcus and colonial Trichodesmium spp., play important roles in the ocean carbon cycle and the biological carbon pump, particularly in the subtropical and tropical gyres (e.g. Partensky et

(C) Inter-Research 2012 - www.int-res.com 
al. 1999, Capone et al. 2005). The ongoing acidification of the surface ocean by dissolution of anthropogenic carbon dioxide from the atmosphere will likely affect the growth of these and other important phytoplankton and therefore their roles in the ocean carbon cycle. While a large number of studies have examined the effect of high $\mathrm{pCO}_{2} / \mathrm{low} \mathrm{pH}$ on various cultured phytoplankton (Hutchins et al. 2009 and references therein), only a few of those studies have focused on the growth and physiology of marine cyanobacteria. Furthermore, mesocosm experiments and incubations with natural autotrophic populations have primarily been done in nutrient-rich systems where cyanobacterial contributions to total autotrophic biomass are low enough to be considered negligible (e.g. Tortell et al. 2002, Engel et al. 2005, Kim et al. 2006, Hare et al. 2007, Riebesell et al. 2007, Sommer et al. 2007, Tortell et al. 2008, Feng et al. 2009).

Most of the research on cyanobacterial responses to changes in $\mathrm{pH} / \mathrm{pCO}_{2}$ has focused on the diazotroph Trichodesmium, which is thought to account for about half of the total $\mathrm{N}_{2}$-fixation in the oceans (Barcelos e Ramos et al. 2007, Hutchins et al. 2007, Levitan et al. 2007, Kranz et al. 2009, 2010). Only 2 studies have examined the response of other diazotrophs: Crocosphaera (Fu et al. 2008) and Nodularia spumigena (Czerny et al. 2009). In nutrientreplete culture studies, increasing $\mathrm{pCO}_{2}$ (decreasing $\mathrm{pH}$ ) consistently resulted in a substantial increase in both $\mathrm{N}_{2}$ fixation (35 to $120 \%$ ) and C fixation (15 to $100 \%)$ by Trichodesmium erythreaum IMS101 due to the alleviation of inorganic $\mathrm{C}$ limitation at low and ambient $\mathrm{pCO}_{2}$ levels. Growth of $\mathrm{T}$. erythreaum at high $\mathrm{pCO}_{2}$ resulted in elevated cellular C:P and $\mathrm{N}: \mathrm{P}$ but not $\mathrm{C}: \mathrm{N}$ ratios. The relative increase in cellular $\mathrm{C}$ and $\mathrm{N}$ quotas was less than the increase in $\mathrm{C}$ - and $\mathrm{N}_{2}$-fixation rates, suggesting the net release of P-depleted DOM at high $\mathrm{pCO}_{2}$ (Hutchins et al. 2007). Increased dissolved organic matter production, relative to particulate organic matter production, at high $\mathrm{pCO}_{2}$ may also be common in natural systems (Yoshimura et al. 2010, Kim et al. 2011) with minimal cyanobacterial populations. To our knowledge, only one study has published similar experiments with natural Trichodesmium populations. Hutchins et al. (2009) report that Trichodesmium colonies collected from a bloom in the Gulf of Mexico increased $\mathrm{N}_{2}$-fixation rates by 6 to $41 \%$ with a doubling of $\mathrm{pCO}_{2}$ from $380 \mathrm{ppm}$ to $750 \mathrm{ppm}$, which is consistent but on the low end of predictions from culture studies. The single cell diazotroph Croccosphaera also demonstrated an increase in C-fixation (20 to $100 \%$ ) and $\mathrm{N}_{2}$-fixation
( 40 to $80 \%$ ) rates at high $\mathrm{pCO}_{2}$ but only under nutrient-replete conditions; iron-limited cultures did not show any response (Fu et al. 2008). A study of the Black Sea diazotroph Nodularia spumigena showed the exact opposite effect of high $\mathrm{pCO}_{2}$, with a $\sim 25 \%$ reduction in $\mathrm{N}_{2}$-fixation and a $\sim 40 \%$ reduction in growth rate (Czerny et al. 2009); this contrasting response may reflect differences between nonheterocystous and heterocystous cyanobacteria, but this is unknown. Based on studies with cultured Trichodesmium, ocean acidification would likely result in a positive feedback on the growth and physiology of natural populations, resulting in a positive change in their role in ocean carbon and nitrogen cycles.

The response of non-diazotrophic cyanobacteria to $\mathrm{pCO}_{2}$ changes is less well understood. Fu et al. (2007) reported that doubling $\mathrm{pCO}_{2}$ alone had no significant effect on the growth of either Synechococcus or Prochlorococcus in culture, whereas 'greenhouse' conditions (doubling $\mathrm{pCO}_{2}$ and increasing temperature by $4^{\circ} \mathrm{C}$ ) significantly increased growth rates, photosynthetic capacity, and cellular pigment levels in Synechococcus but not Prochlorococcus. These different responses between Synechococcus and Prochlorococcus have been attributed to differences in inorganic carbon acquisition systems associated with carbon limitation at low $\mathrm{pCO}_{2}$ in Synechococcus (Fu et al. 2007). In contrast, an enclosure experiment that compared the growth of the natural phytoplankton assemblage (stimulated by addition of nutrients, $10 \mu \mathrm{mol} \mathrm{l}{ }^{-1} \mathrm{NO}_{3}{ }^{-}$and $0.5 \mu \mathrm{mol} \mathrm{l} \mathrm{l}^{-1} \mathrm{PO}_{4}{ }^{-3}$ ) at 3 levels of $\mathrm{pH} / \mathrm{pCO}_{2}$ found the only significant difference to be a lower abundance of Synechococcus and a higher abundance of picoeukaryotes at high $\mathrm{pCO}_{2}$ (Paulino et al. 2008). The response of natural cyanobacterial populations to elevated $\mathrm{pCO}_{2}$ in the nutrient-deplete subtropical and tropical seas remains an important gap in our knowledge of the changing ocean (Rost et al. 2008, Hutchins et al. 2009), particularly given the potential for increased areal extent of the oligotrophic gyres due to ocean warming and increased stratification (e.g. Boyd \& Doney 2002).

Here, we report the results of several experiments carried out between July 2009 and April 2010 at the Bermuda Atlantic Time-series Study (BATS) station where we examined the C-fixation responses of natural assemblages dominated by Synechococcus and Prochlorococcus and the $\mathrm{N}_{2}$ - and C-fixation responses of isolated Trichodesmium colonies to $\mathrm{pH}$ manipulations. Seasonally, the phytoplankton community at BATS shifts from a spring bloom community co-dominated by nanoeukaryotes, in particular members of the haptophyte group, and Synechococ- 
cus (e.g. Lomas et al. 2010) to a community dominated by cyanobacteria, of all 3 genera, in late summer (e.g. Orcutt et al. 2001, Steinberg et al. 2001). Of particular note with respect to the goals of the present study is the well documented slow acidification of the surface ocean at BATS (Bates 2007) and the increasing contribution of Synechococcus biomass (and the decreasing importance of larger eukaryotes) during the winter/spring bloom (Lomas et al. 2010) over the past 2 decades.

\section{MATERIALS AND METHODS}

\section{Field site and experimental design}

Experiments were carried out on board the RV 'Atlantic Explorer' at the BATS site $\left(31^{\circ} 40^{\prime} \mathrm{N}\right.$, $\left.64^{\circ} 10^{\prime} \mathrm{W}\right)$, located in the subtropical North Atlantic Ocean $\sim 86 \mathrm{~km}$ south-east of Bermuda. Trichodesmium thiebautii colonies were collected with a $330 \mu \mathrm{m}$ net that was hand-towed through the surface mixed-layer $(\sim 20 \mathrm{~m})$. Colonies were picked and rinsed in $0.22 \mu \mathrm{m}$ filtered seawater immediately after the tow and distributed into duplicate experimental bottles filled with filtered $(0.2 \mu \mathrm{m})$ surface seawater where the $\mathrm{pH}$ had been adjusted to represent past $(\mathrm{pH} \sim 8.4)$ and future $(\mathrm{pH} \sim 7.8)$ conditions (see section
'pH/pCO $\mathrm{CO}_{2}$ manipulation') as well as a control bottle with no $\mathrm{pH}$ adjustment. Both $\mathrm{pH}$ treatments and the controls were supplemented with $50 \mathrm{nmol} \mathrm{l^{-1 }}$ phosphate and $5 \mathrm{nmol} \mathrm{l}^{-1} \mathrm{FeCl}_{3}$ ('incubation media'). In Expts A-D, the colonies were allowed to acclimate for $24 \mathrm{~h}$ in a shaded (30\% surface irradiance) flowthrough incubator, while in Expts $\mathrm{E}$ to $\mathrm{I}$, rate measurements were begun immediately (Table 1). Colonies in Expts A to D were visually examined after acclimation and showed no obvious detrimental effects of the acclimation period, and all colonies initially added were accounted for after the acclimation period.

For experiments with the bulk phytoplankton community, water was collected using either a rosette sampler (March and April) or a trace-metal clean diaphragm pump (September), gently mixed in a shaded polycarbonate carboy, and dispensed into triplicate acid-washed polycarbonate bottles. Samples were collected from the approximate mid-point of the mixed layer, which in September was $\sim 10 \mathrm{~m}$, in March $\sim 50 \mathrm{~m}$, and in April $\sim 35 \mathrm{~m}$. After $\mathrm{pH} / \mathrm{pCO}_{2}$ adjustment, the following nutrient combinations were added: P-limited treatment: $5 \mu \mathrm{mol} \mathrm{l} \mathrm{l}^{-1} \mathrm{NO}_{3}$, $5 \mu \mathrm{mol} \mathrm{l} \mathrm{l}^{-1} \mathrm{Si}, 2 \mathrm{nmol} \mathrm{l^{-1 }} \mathrm{Fe}$; N-limited treatment: $0.5 \mu \mathrm{mol} \mathrm{l}^{-1} \mathrm{PO}_{4}, 5 \mu \mathrm{mol} \mathrm{l}{ }^{-1} \mathrm{Si}, 2 \mathrm{nmol} \mathrm{l}{ }^{-1} \mathrm{Fe}$; Replete: $5 \mu \mathrm{mol} \mathrm{l} \mathrm{l}^{-1} \mathrm{NO}_{3}, 0.5 \mu \mathrm{mol} \mathrm{l} \mathrm{l}^{-1} \mathrm{PO}_{4}, 5 \mu \mathrm{mol}{ }^{-1} \mathrm{Si}, 2 \mathrm{nmol}$ $\mathrm{l}^{-1} \mathrm{Fe}$. Bottles were placed in a flow-through incuba-

Table 1. Ambient environmental data associated with Trichodesmium and natural population experiments. SST: sea surface temperature

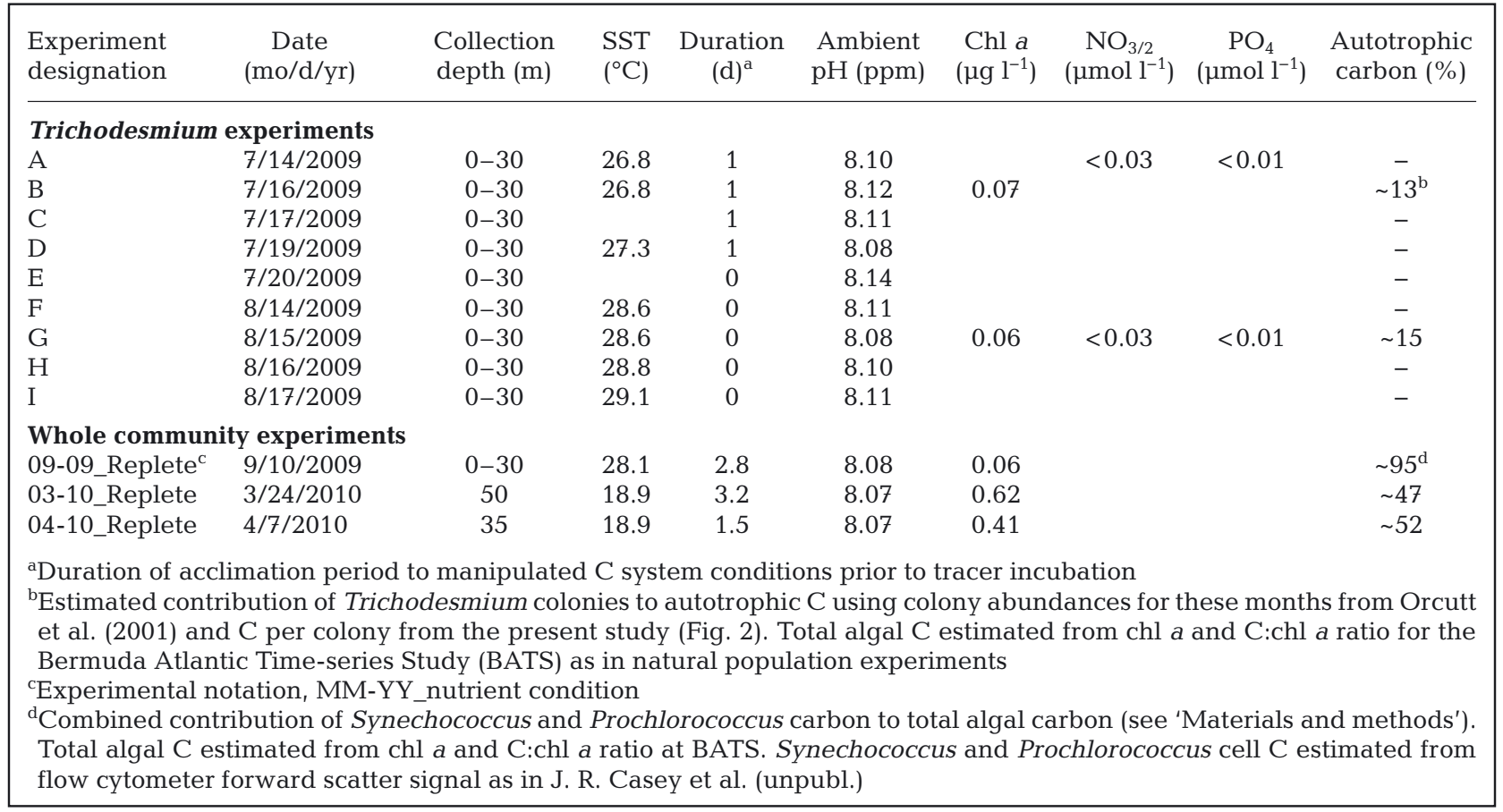


tor shaded to $\sim 30 \%$ of surface irradiance. In many cases, rate measurements were made immediately after $\mathrm{pH} / \mathrm{pCO}_{2}$ adjustment/nutrient amendment, but in all experiments, the community was allowed to grow for 1 to $3 \mathrm{~d}$ under $\mathrm{pH}$-adjusted conditions prior to final measurement of C-fixation and other parameters. Final nutrient, but not Fe, concentrations were measured. With the exception of the N-limited treatments, dissolved inorganic nitrogen concentrations were $>1 \mathrm{umol} \mathrm{l}^{-1}$.

\section{pH/pCO $\mathrm{CO}_{2}$ manipulation}

In all the low $\mathrm{pH}$ experiments, the $\mathrm{pH}$ was reduced to $\sim 7.8$, the approximate predicted year 2100 value. We used only high-purity $\mathrm{HCl}$ addition for the Trichodesmium incubations to minimize the chance of contamination. For the longer lasting incubations with bulk phytoplankton in which the DIC drawdown might have become substantial, we added equimolar additions of high-purity $\mathrm{HCl}$ and $\mathrm{NaHCO}_{3}$, effectively mimicking the ongoing rise in $\mathrm{CO}_{2}$, which also increases DIC. As shown by Shi et al. (2009), the method makes no difference as long as the DIC drawdown is small. In the high $\mathrm{pH}$ experiments, the $\mathrm{pH}$ was increased to 8.4, similar to last glacial minimum values, using high-purity $\mathrm{NaOH}$. The $\mathrm{pH}$ was measured using an electrode calibrated on the USA National Bureau of Standards scale. These measurements were converted to the total hydrogen ion scale by intercalibration with spectrophotometric measurements of $\mathrm{pH}$ (on the total hydrogen ion scale) using thymol blue (Zhang \& Byrne 1996). All pH values are reported on the total hydrogen ion scale. Based on $\mathrm{pH}$ and average DIC concentrations at BATS (N. Bates pers. comm.), the estimated $\mathrm{pCO}_{2}$ values for each treatment were as follows: low pH: 800 to 820 ppm $\mathrm{CO}_{2}$, ambient $\mathrm{pH}$ : 350 to 405 ppm $\mathrm{CO}_{2}$, high pH: 150 to 165 ppm $\mathrm{CO}_{2}$ (Lueker et al. 2000). pH measurements are a very good indicator of change in $\mathrm{CO}_{2}$ concentrations due to consumption or gas exchange (Gattuso et al. 2010). Values changed little between the beginning and the end of the incubation, suggesting that the carbon system was stable (data not shown).

\section{Biomass measurements}

Chlorophyll a (chl a) samples were collected by gentle vacuum filtration onto glass fiber filters (GF/F) and stored in liquid nitrogen. Onshore, the filters were extracted overnight in a $90 \%$ acetone and $10 \%$ water solution at $-20^{\circ} \mathrm{C}$, and chl a was quantified fluorometrically (Parsons et al. 1984). Particulate organic material was collected by gentle filtration on precombusted $\mathrm{GF} / \mathrm{F}$ filters and stored at $-20^{\circ} \mathrm{C}$. Prior to analysis, the filters were exposed to fuming $\mathrm{HCl}$ to remove inorganic carbon and then dried in an oven at $60^{\circ} \mathrm{C}$. Particulate organic carbon (POC) and nitrogen (PON) masses and isotopic composition were measured using an elemental analyzer coupled to an isotope ratio mass spectrometer (e.g. Orcutt et al. 2001). Particulate organic phosphorus (POP) was analyzed on a magnetic sector field HR-ICP-MS (Element 2, ThermoFinnigan) following the method of Tang \& Morel (2006).

\section{Rate measurements}

Trichodesmium thiebautii colonies (in incubation media) were sealed in $30 \mathrm{ml}$ glass serum vials to which ${ }^{15} \mathrm{~N}_{2}$ gas (Cambridge Isotope Laboratory, 98\% enriched) and ${ }^{13} \mathrm{C}-\mathrm{NaHCO}_{3}(\mathrm{Cambridge}$ Isotope Lab-

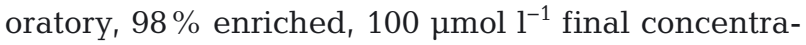
tion for an atom $\%$ enrichment of $4.5 \%$; the addition alters $\mathrm{pH}$ by $\leq 0.02$ units) were added and then incubated for 6 to $8 \mathrm{~h}$ around local noon at $\sim 30 \%$ incident irradiance in a flow-through incubator (Orcutt et al. 2001). $N_{2}$-fixation rates were quantified based on the incorporation of ${ }^{15} \mathrm{~N}_{2}$ into biomass and calculated following the methods of Montoya et al. (1996). Cfixation rates were measured by quantifying the incorporation of ${ }^{13} \mathrm{C}-\mathrm{NaHCO}_{3}$ into particulate biomass and calculated using equations analogous to those for $\mathrm{N}_{2}$-fixation (e.g. Slawyk et al. 1977). DIC concentrations for these calculations were estimated from the BATS climatology (e.g. Bates et al. 1996). Relative changes in $\mathrm{N}_{2}$ - and C-fixation rates were calculated as follows:

$$
\text { fractional change }=\frac{\left(R_{\mathrm{trt}}-R_{\mathrm{amb}}\right)}{R_{\mathrm{amb}}}
$$

where $R_{\text {trt }}$ is the rate for a treatment (either high or low $\mathrm{pH}$ ), and $R_{\mathrm{amb}}$ is the rate at ambient $\mathrm{pH}$.

For the bulk phytoplankton community experiments, C-fixation rates were measured using ${ }^{14} \mathrm{C}$ bicarbonate. To a $100 \mathrm{ml}$ seawater sample, $5 \mu \mathrm{Ci}$ ${ }^{14} \mathrm{C}$-bicarbonate was added, incubated for 2 to $3 \mathrm{~h}$, centered on local noon, at $\sim 30 \%$ incident irradiance in a flow-through incubator, and then gently filtered through a GF/F filter. The filter was saturated with $2 \% \mathrm{HCl}$ and allowed to degas overnight to remove inorganic carbon before addition of scin- 
tillation fluid and counting on a Perkin Elmer TriCarb 2900 TR low activity liquid scintillation analyser. Samples for total ${ }^{14} \mathrm{C}$ activity added were taken at the beginning of the incubation and preserved with an equal volume of $\beta$-phenethylamine. $C$-fixation rates were calculated based upon the calculated ${ }^{14} \mathrm{C}$ specific activity for each experiment and activity retained in the particulate fraction (Hopkinson et al. 2010).

\section{Flow cytometry}

Samples for analytical flow cytometric analysis were collected from the whole community experiments and fixed with paraformaldehyde $(0.5 \%$ final concentration, $\sim 4^{\circ} \mathrm{C}$ for 1 to $2 \mathrm{~h}$ ) before storage in liquid nitrogen until analysis. Samples were analyzed on a Becton Dickinson (formerly Cytopeia) influx cytometer as described by Lomas et al. (2010). Cyanobacteria were identified as either Synechococcus or Prochlorococcus based on cell size and the presence or absence of phycoerythrin, respectively. Based upon these gating criteria, the number of cells in each identified population was enumerated and converted to cell abundances using the volume analyzed method (Sieracki et al. 1993). Geometric mean values of red fluorescence (relative chlorophyll content), orange fluorescence (relative phycoerythrin content), and forward laser scatter (FSC, relative size) for gated Synechococcus and Prochlorococcus populations were calculated using FCS Express v3.0. The geometric mean FSC signals for Synechococcus and Prochlorococcus were used to calculate mean cellular POC using a direct $\mathrm{POC}_{\text {cell }}$ vs. FSC calibration curve specific to this instrument (J. R. Casey et al. unpubl.). In brief, the geometric mean FSC and $\mathrm{POC}_{\text {cell }}$ (via elemental analyzer) were determined on a wide range of cultures and flow cytometrically sorted natural populations up to $\sim 20 \mu \mathrm{m}$ in size. A robust direct correlation was found between mean FSC and $\mathrm{POC}_{\text {cell }}$ regardless of sample origin or size. In the present study, the mean FSC Synechococcus and Prochlorococcus was used to calculate $\mathrm{POC}_{\text {cell, }}$ and this $\mathrm{POC}_{\text {cell }}$ value was converted to POC per taxonomic population by multiplying by abundance, summed across Synechococcus and Prochlorococcus, and expressed as a percentage of the total autotrophic $\mathrm{C}$ estimated from $\mathrm{chl} a$ and the $\mathrm{C}$ : $\mathrm{chl}$ a ratio for each cruise (data not shown).
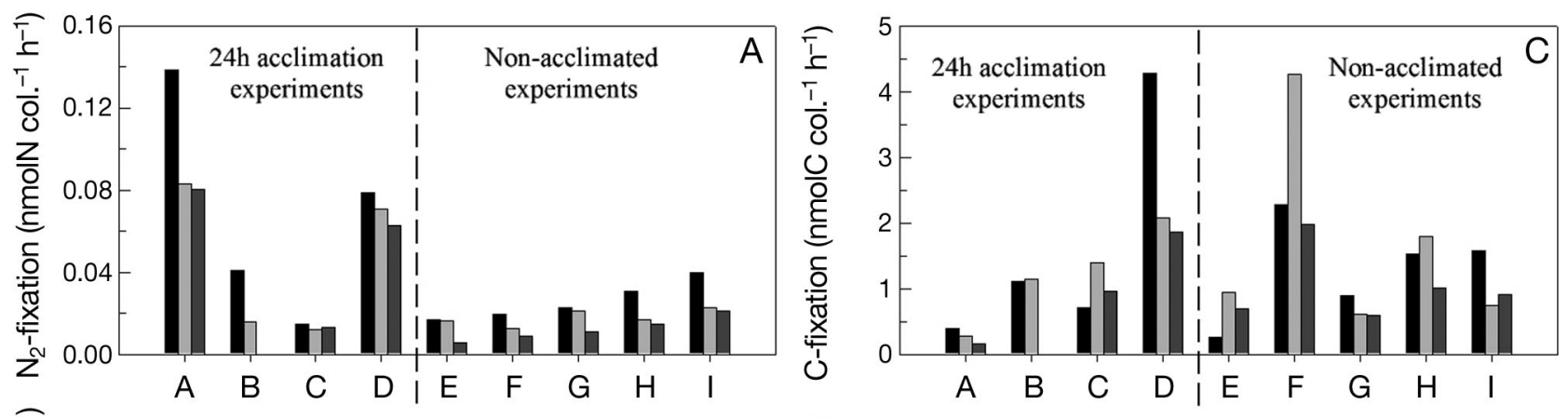

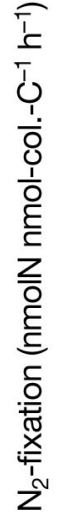
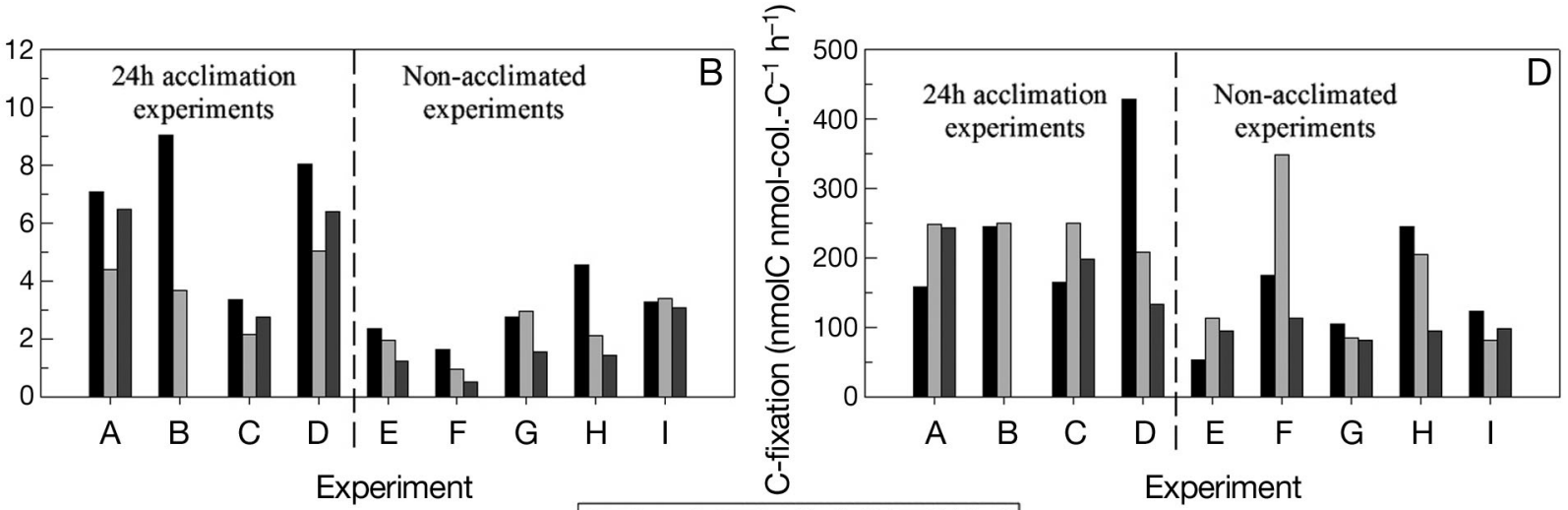

Fig. 1. Trichodesmium thiebautii. $(\mathrm{A}, \mathrm{B}) \mathrm{N}_{2}$ - and $(\mathrm{C}, \mathrm{D}) \mathrm{C}$-fixation rates in response to low (black), ambient (light grey) and high (dark grey) $\mathrm{pH}$ for each of the 9 independent experiments, in terms of $\mathrm{N}$ or $\mathrm{C}$ fixed $(\mathrm{A}, \mathrm{C})$ per colony $(\mathrm{col}$.) or $(\mathrm{B}, \mathrm{D})$ normalized to colony $\mathrm{C}$ content. See Table 1 for experimental descriptions 


\section{RESULTS AND DISCUSSION}

\section{Trichodesmium incubations}

Colony normalized $\mathrm{N}_{2}$-fixation rates at ambient $\mathrm{pH} / \mathrm{pCO}_{2}$ averaged $( \pm \mathrm{SD}) 0.031 \pm 0.026$ (range 0.014 to $0.082 ; \mathrm{n}=9$; Fig. $1 \mathrm{~A}) \mathrm{nmol} \mathrm{N}$ colony ${ }^{-1} \mathrm{~h}^{-1}$, which is at the low end of rates previously measured at BATS using ${ }^{15} \mathrm{~N}_{2}$ incubations (0.05 to $0.5 \mathrm{nmol} \mathrm{N}$ colony $^{-1} \mathrm{~h}^{-1}$; Orcutt et al. 2001). A possible reason for this is the size of the colonies sampled. Orcutt et al. (2001) measured an average colony $\mathrm{N}$ quota of $\sim 100$ to $200 \mathrm{nmol} \mathrm{N}$ colony $^{-1}$ which is slightly higher than the values of $\sim 50$ to

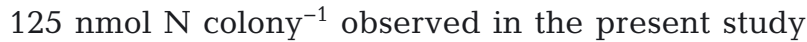
(Fig. 2A). Due to the possibility of changes in colony size or elemental composition between sampling points, $\mathrm{N}_{2}$-fixation rates were also normalized to colony POC (Fig. 1C,D). In all 9 Trichodesmium theibautii experiments, nutrient-replete (see 'Methods') $\mathrm{N}_{2}$-fixation rates increased at low $\mathrm{pH}$ relative to rates at ambient $\mathrm{pH}$ with no significant difference (Student's $t$-test, $\mathrm{p}=0.372$ ) between experiments with $\left(0.032 \pm 0.026 \mathrm{~N}\right.$ colony $\left.^{-1} \mathrm{~h}^{-1}\right)$ and without $\left(0.030 \pm 0.029 \mathrm{~N}\right.$ colony $\left.^{-1} \mathrm{~h}^{-1}\right)$ the $24 \mathrm{~h}$ acclimation period (Fig. 1A). Further, normalization to colony $\mathrm{C}$ did not change the general pattern of data, and $\mathrm{N}_{2}$ fixation rates were significantly higher (Student's $t$-test; $\mathrm{p}<0.01$ ) at low $\mathrm{pH}$ (Table 2). On average, the $\mathrm{N}_{2}$-fixation rate at low pH was $54 \%$ (range 6 to $156 \%$ ) greater (HSD and $t$-tests, $\mathrm{p}<0.05$ ) than at ambient $\mathrm{pH}$ conditions (Table 2). The results of our field experiments with $T$. thiebautii are very similar, qualitatively and quantitatively, with those obtained in cultures of $T$. erythraeum (Barcelos e Ramos et al. 2007, Hutchins et al. 2007, Levitan et al. 2007) and Trichodesmium spp. from the Gulf of Mexico (Hutchins et al. 2009). $\mathrm{N}_{2}$-fixation rates decreased in all but one incubation at high $\mathrm{pH}$ relative to ambient $\mathrm{pH}$ (Fig. 1A, Table 2). $\mathrm{N}_{2}$-fixation rates at high $\mathrm{pH}$ were on average $21 \%$ (range 4 to $63 \%$ ) lower than at ambient $p \mathrm{H}$ (HSD and $t$-tests, $\mathrm{p}<0.05$, Table 2) but still measurable at $0.027 \pm 0.028 \mathrm{nmol} \mathrm{N}$ colony $^{-1}$ $\mathrm{h}^{-1}$. This is in contrast to the findings of Hutchins et al. (2007), who found that at low $\mathrm{pCO}_{2}(\sim 180 \mathrm{ppm}$, similar to our low $\mathrm{pH}$ experiment), cultured $T$. erythraeum would not grow. This finding suggests that there may be species-specific thresholds for growth at low $\mathrm{pCO}_{2}$ or that natural populations of Trichodesmium have a greater resilience to low $\mathrm{pCO}_{2}$, and perhaps other sub-optimal environmental conditions, than cultured representatives; this highlights the need to study the effects of ocean acidification with natural planktonic assemblages as well as cultured representatives.

The C-fixation rates were more variable but nonetheless show that in 6 out of 9 experiments, C-fixation rates decreased with increasing $\mathrm{pH}$ (Fig. 1C). On average, C-fixation rates were 22 to $24 \%$ (range -53 to $23 \%$ ) lower at high $\mathrm{pH}$ than at ambient $\mathrm{pH}$ and $37 \%$ (-72 to $112 \%$ ) lower than at low $\mathrm{pH}$, but the differences were not significant regardless of normalization (Table 2). These relative changes are in good agreement with previous work in cultures of
Fig. 2. Trichodesmium thiebautii. Biochemical characterization in response to changes in $\mathrm{pH}$. (A) Chlorophyll a (chl a) per colony (col.) (left partition), particulate organic nitrogen (PON) per colony (middle partition), and particulate organic carbon (POC) per colony (right partition). (B) Colony C:chl a ratio (left partition) and colony $\mathrm{C}: \mathrm{N}$ ratio (right partition). $\mathrm{x}$ : values for all experiments grouped by $\mathrm{pH}$ treatment; filled circle: mean. L, A, H represent low, ambient and high $\mathrm{pH}$ treatments, respectively 
Table 2. Fractional changes in $\mathrm{N}_{2}$ - and $\mathrm{C}$-fixation rates at high and low $\mathrm{pH}$ relative to rates measured at ambient $\mathrm{pH}$. Data are presented for colony normalized and colony (col.) C normalized rates. Negative values represent decreases in rates relative to rates at ambient $\mathrm{pH}$. Statistical tests report values for low $\mathrm{pH}$ vs. high $\mathrm{pH}$ comparisons for the same normalized rate measurements. nd: no data

\begin{tabular}{|c|c|c|c|c|c|c|c|c|}
\hline \multirow[t]{2}{*}{ Experiment } & \multicolumn{2}{|c|}{$\begin{array}{c}\mathrm{N}_{2} \text {-fixation } \\
\text { (nmol N col. }{ }^{-1} \mathrm{~h}^{-1} \text { ) }\end{array}$} & \multicolumn{2}{|c|}{$\begin{array}{c}\mathrm{N}_{2} \text {-fixation } \\
\text { (nmol N nmol-col.- } \mathrm{C}^{-1} \mathrm{~h}^{-1} \text { ) }\end{array}$} & \multicolumn{2}{|c|}{$\begin{array}{c}\text { C-fixation } \\
\left(\mathrm{nmol} \mathrm{C} \text { col. }^{-1} \mathrm{~h}^{-1}\right)\end{array}$} & \multicolumn{2}{|c|}{$\begin{array}{c}\text { C-fixation } \\
\left(\text { nmol C nmol-col.- } \mathrm{C}^{-1} \mathrm{~h}^{-1}\right)\end{array}$} \\
\hline & Low $\mathrm{pH}$ & High pH & Low $\mathrm{pH}$ & High pH & Low pH & High pH & Low $\mathrm{pH}$ & High pH \\
\hline $\mathrm{A}$ & 0.66 & -0.04 & 0.62 & 0.47 & 0.40 & -0.44 & -0.36 & -0.02 \\
\hline B & 1.56 & nd & 1.44 & nd & -0.03 & nd & -0.02 & nd \\
\hline $\mathrm{C}$ & 0.22 & 0.11 & 0.57 & 0.28 & -0.49 & -0.31 & -0.34 & -0.20 \\
\hline $\mathrm{D}$ & 0.11 & -0.11 & 0.60 & 0.27 & 1.06 & -0.10 & 1.06 & -0.36 \\
\hline E & 0.06 & -0.63 & 0.21 & -0.37 & -0.72 & -0.27 & -0.53 & -0.16 \\
\hline $\mathrm{F}$ & 0.57 & -0.29 & 0.678 & -0.46 & -0.47 & -0.53 & -0.50 & -0.67 \\
\hline $\mathrm{G}$ & 0.10 & -0.48 & -0.07 & -0.48 & 0.45 & -0.04 & 0.24 & -0.03 \\
\hline $\mathrm{H}$ & 0.82 & -0.12 & 1.17 & -0.32 & -0.14 & -0.44 & 0.20 & -0.54 \\
\hline I & 0.74 & -0.09 & -0.04 & -0.09 & 1.12 & 0.23 & 0.52 & 0.21 \\
\hline Average & 0.54 & -0.21 & 0.58 & -0.09 & 0.13 & -0.24 & 0.03 & -0.22 \\
\hline $\mathrm{SD}$ & 0.49 & 0.24 & 0.51 & 0.38 & 0.67 & 0.25 & 0.53 & 0.29 \\
\hline Statistic & \multicolumn{2}{|c|}{$\begin{array}{l}\text { Student's } t \text {-test } \\
\mathrm{p}=0.001\end{array}$} & \multicolumn{2}{|c|}{$\begin{array}{l}\text { Student's } t \text {-test } \\
p=0.009\end{array}$} & \multicolumn{2}{|c|}{$\begin{array}{l}\text { Mann-Whitney rank } \\
\text { sum } p=0.36\end{array}$} & \multicolumn{2}{|c|}{$\begin{array}{c}\text { Mann-Whitney rank } \\
\text { sum } p=0.31\end{array}$} \\
\hline
\end{tabular}

Trichodesmium erythraeum, which showed a 15 to $128 \%$ increase in C-fixation from present conditions to future high $\mathrm{pCO}_{2}$ conditions $(750 \mathrm{ppm}$; Hutchins et al. 2007). The two experiments where C-fixation rates decreased at low $\mathrm{pH}(\mathrm{C}$ and $\mathrm{G}$; Fig. 1B) were also 2 of the lowest in terms of $\mathrm{N}_{2}$-fixation response, suggesting that some other constraint in those experiments may have mitigated the response to changing $\mathrm{pCO}_{2}$.

The increases in $\mathrm{N}_{2}$-fixation and $\mathrm{C}$-fixation under nutrient-replete, low $\mathrm{pH}$ conditions are consistent with the upregulation of cellular machinery leading to enhancement of growth rates (growth rates themselves were not likely to have increased over this short acclimation and measurement period) as previously shown (Barcelos e Ramos et al. 2007, Hutchins et al. 2007, Levitan et al. 2007). There are at least 2 possible physiological explanations for this observation. First, it is possible that the specific activity of the enzymes mediating these rate processes (i.e. nitrogenase and RUBISCO) changes in response to changes in $\mathrm{pH}$ (Levitan et al. 2010). Second, upregulation may be attributed to reallocation of cellular energy demand from the $\mathrm{C}$ concentrating mechanism allowing for enhancement of overall cellular growth rates (Kranz et al. 2010). Genetic evidence suggests Trichodesmium has a C concentrating mechanism similar to other cyanobacteria (Badger et al. 2006); however, the observation that C-fixation at high $\mathrm{pH}$ is depressed at short (Fig. 1) and acclimated timescales (Hutchins et al. 2007) suggests that the ability to acquire inorganic carbon is limited or ener- getically expensive at ambient and lower $\mathrm{pCO}_{2}$ levels. Consistent with the hypothesized upregulation of cellular growth at low $\mathrm{pH}$ is an average increase in mean colony chl a content at high $\mathrm{pCO}_{2}$ relative to chl a per colony at low $\mathrm{pCO}_{2}$ (Fig. 2A; 1-way ANOVA, $p=0.108$ ), which would provide the additional cellular energy needed for the energy intensive pathways of $\mathrm{N}_{2}$ - and $\mathrm{C}$-fixation. However, we do not have data on variable fluorescence that would explain whether the hypothesized change in energy allocation is due to increased energy transfer efficiency or due to changes in chl $a$ and therefore total light harvested. The average increase in the colony $\mathrm{C}$ :chl a ratio with increasing pH (Fig. 2B) might suggest the latter, but this remains to be determined. Interestingly, there was a slight, but not significant (1-way ANOVA, p = 0.099), decrease in the particulate $\mathrm{C}: \mathrm{N}$ ratio during incubation at high $\mathrm{pH}(\mathrm{C}: \mathrm{N}=$ $7.5 \pm 0.83)$ and low $\mathrm{pH}(\mathrm{C}: \mathrm{N}=6.5 \pm 0.85$; Fig. 2B), consistent with the slightly higher stimulation of colony-normalized $\mathrm{N}_{2}$-fixation relative to C-fixation (Fig. 1). The ratio of $\mathrm{C}$ and $\mathrm{N}$-specific uptake rates (i.e. $\mathrm{N}_{2}$ fixation normalized to colony $\mathrm{N}$ and $\mathrm{C}$ fixation normalized to colony $\mathrm{C}$ ) at high $\mathrm{pH}$ (ratio $=6.6 \pm$ $2.9)$ and low $\mathrm{pH}(6.3 \pm 2.3)$ also suggests little change in the cellular demand for $\mathrm{C}: \mathrm{N}$ as a function of inorganic carbon cycle changes (data not shown). Further research is required to determine whether this stability of the cellular $\mathrm{C}: \mathrm{N}$ ratio is actively controlled by physiological mechanisms (e.g. changes in enzyme specific activity) and whether there are conditions under which they become uncoupled. 


\section{Whole community incubations}

During September 2009, March 2010, and April 2010, similar incubation experiments were performed at varying $\mathrm{pH} / \mathrm{pCO}_{2}$ with the natural phytoplankton assemblage, of which 47 to $95 \%$ of the autotrophic carbon biomass was attributed to Prochlorococcus and Synechococcus (Table 1). The remainder of the autotrophic biomass was dominated by pico- and nanoeukaryotes (data not shown). When ${ }^{14} \mathrm{C}$ experiments were performed immediately after $\mathrm{pH}$ adjustment and nutrient addition (September and March only), a significant ( $\mathrm{p}=$ $0.002, t$-test, 2-tailed distribution) increase in chl a normalized $\mathrm{C}$-fixation (i.e. assimilation number) with decreasing $\mathrm{pH}$ was observed (Table 3). The relative change in assimilation number over the full experimental $\mathrm{pH}$ range was 25 to $33 \%$ (Table 3). This differential effect was short-lived as no significant difference in assimilation number between $\mathrm{pCO}_{2}$ conditions was observed after 1 to $3 \mathrm{~d}$ of incubation in any treatment or month (Table 3). There were differences between the initial and final assimilation number values, likely due to variable nutrient status in the various treatments at the end of the incubation. For example, in all P-limited and replete incubations during all of the cruises, the chl a concentration (as a proxy for biomass) and Synechococcus cell number consistently increased. In the March and April experiments, chl a increased to $>2 \mathrm{\mu g} \mathrm{l}^{-1}$, which likely resulted in substantial consumption of added nutrients, whereas in September, chl $a$ also increased 3-fold but remained $<0.2 \mu \mathrm{g} \mathrm{l}{ }^{-1}$, and nutrients were not substantially reduced. Regardless of the treatment or month, the relative change in assimilation number over the full range of $\mathrm{pH}$ treatments did not exceed $18 \%$ and averaged 11 $\pm 7 \%$. These results suggest that natural phytoplankton assemblages dominated by cyanobacteria have the ability to immediately respond, via changes in assimilation number, to either increases or decreases in the ambient $\mathrm{pCO}_{2}$ condition. On the acclimation time scale (days), however, the assimilation numbers equalized, likely through adjustment of the $\mathrm{C}$ concentrating mechanism. Therefore, the $\mathrm{pCO}_{2}$ response in single cell cyanobacteria, unlike that observed above for Trichodesmium, appears to be transient. On the timescale of cell division, photosynthesis adjusts to optimize growth at the new conditions, and therefore, cell growth is unlikely to be controlled by changes in the inorganic carbon cycle but rather by macronutrient or micronutrient availability (Beardall et al. 2009).
As expected, net cell growth was low and did not vary with $\mathrm{pH}$ treatment in either the P-limited 'control' or P-replete treatments. The trends in net growth across $\mathrm{pH}$ treatments were not consistent between nutrient treatments (Table 3). Synechococcus cell numbers increased with decreasing $\mathrm{pH}$ in the absence of added phosphate but decreased with decreasing $\mathrm{pH}$ when phosphate was added. The same general pattern as a function of $\mathrm{pH}$ held for Prochlorococcus. However, overall, there was a substantial drop in cell abundance between initial values and those at the end of the incubation. These data support prior research that tight grazer control on picoplankton under increasing $\mathrm{pCO}_{2}$ might be maintained as long as the picoplankton community composition does not change significantly, as was the case in these experiments (Rose et al. 2009). In addition, they suggest that there may be an interaction between nutrient status and $\mathrm{pH}$ manipulation that should be considered further in additional experiments, but treatment responses are likely to be small.

Because the cyanobacteria were analyzed using flow cytometry, information was also gained on relative cell size and pigment content (assessed by fluorescence) for Synechococcus and Prochlorococcus as a function of $\mathrm{pH}$ and nutrient conditions. Cell size (based upon forward light scatter as a proxy) changed little $(\leq 20 \%)$ between the initial population and most nutrient treatments and was only related to $\mathrm{pH}$ (increasing with increasing $\mathrm{pH}$ ) in the September experiment for Synechococcus (Table 3). In March, the mean cellular chl $a$ and phycoerythrin fluorescence for Synechococcus and Prochlorococcus decreased $\sim 50 \%$ in all tests, likely due to photoacclimation, as cells were incubated at irradiances higher than what they were exposed to in the field. Consistent with this explanation is the much smaller reduction in cellular pigment fluorescence during the incubation in April when the mixed layer depth had shoaled to $\sim 60 \mathrm{~m}$ within the euphotic zone ( $95 \mathrm{~m}$; Siegel et al. 2001) from the $>200 \mathrm{~m}$ in March (BATS unpubl. data). Cellular pigments, both chl $a$ and phycoerythrin, were largely independent of changes in $\mathrm{pH}$ treatment, with the exception of Synechococcus in September, which showed a consistent decrease in pigment per cell with a decrease in $\mathrm{pH}$ (Table 3). Prochlorococcus exhibited no change in cellular pigment levels in response to $\mathrm{pH}$ or nutrient treatments, suggesting that the 2 important single cell cyanobacteria do not have the same physiological response to the same environmental manipulations. Our data from the fall and spring cruises when 


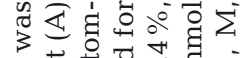

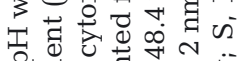

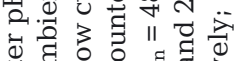

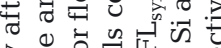

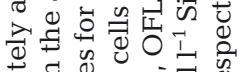

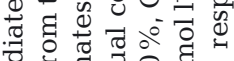

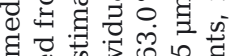

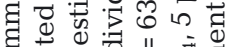

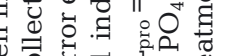

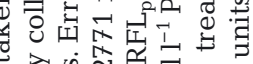

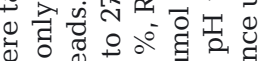
3 o 0 in in ơ

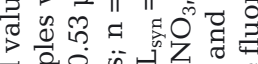

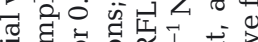

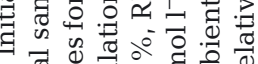

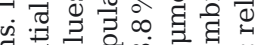

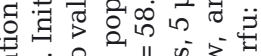

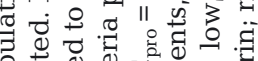

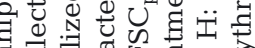

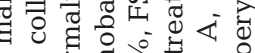
車 녕

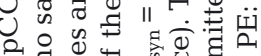

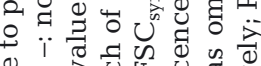

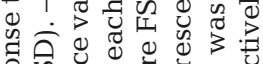

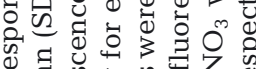

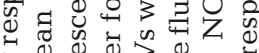

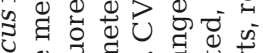

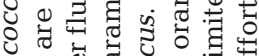
O

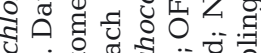

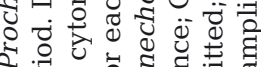

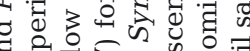

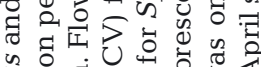
y

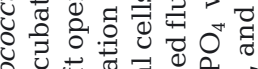
政

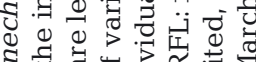

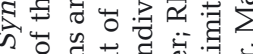

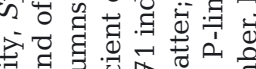

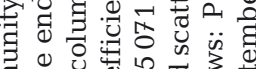

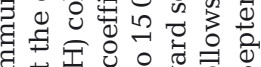

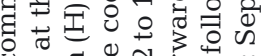

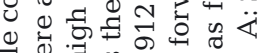

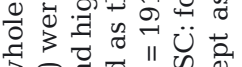

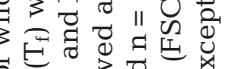

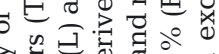

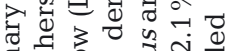

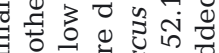
年娄

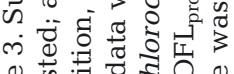

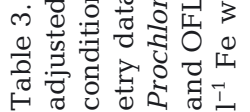

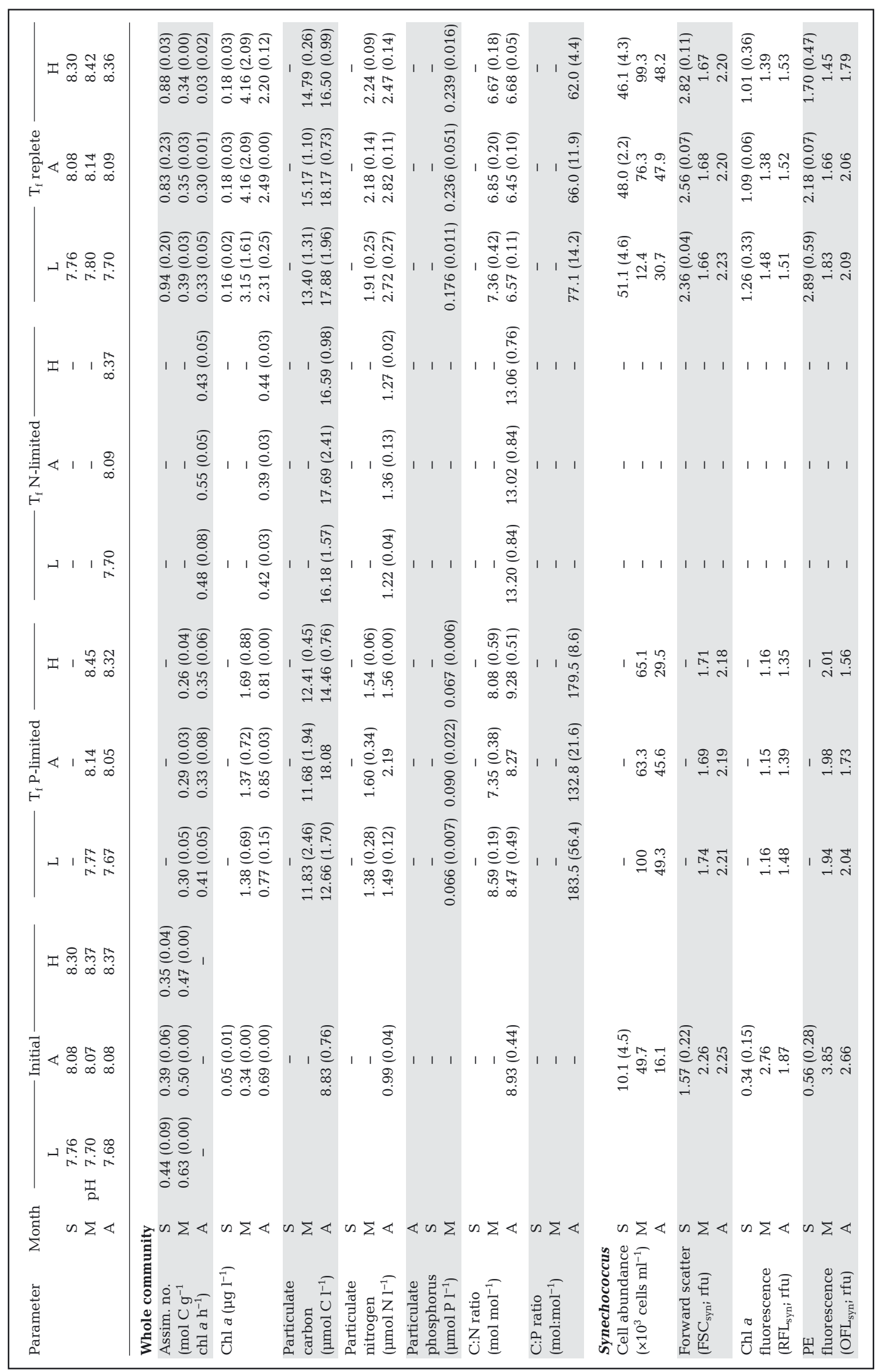




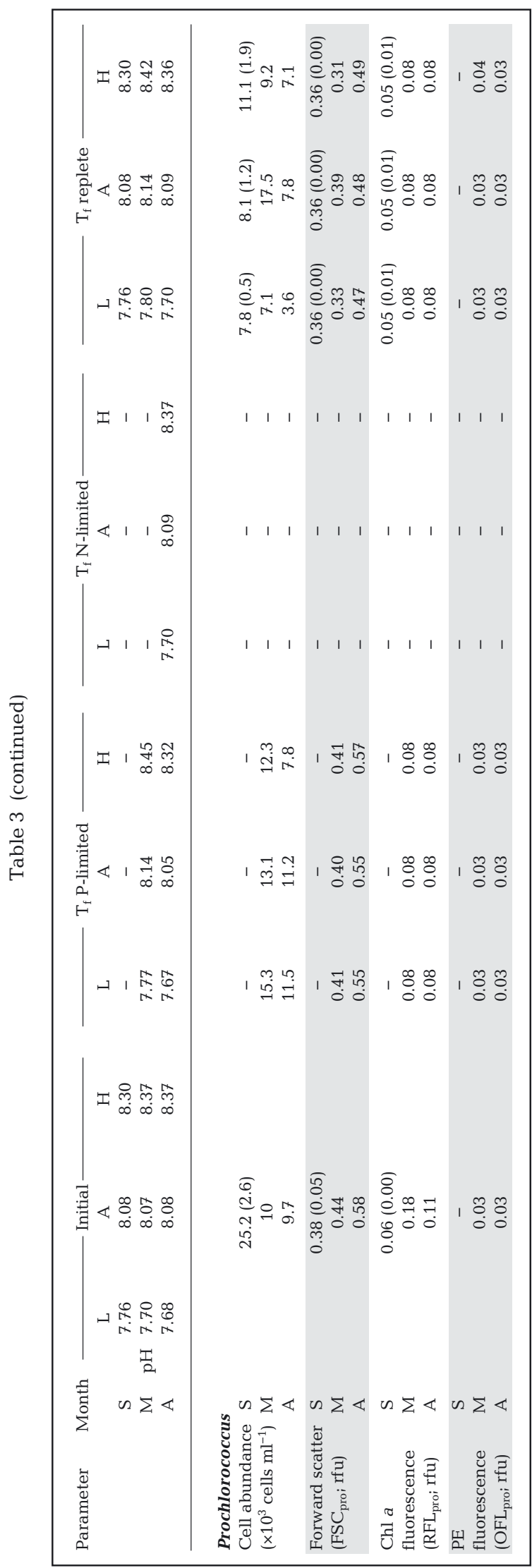

cyanobacteria are very important contributors to autotrophic carbon biomass show relatively little direct effect of $\mathrm{pH}$ on net growth (by changes in cell number), carbon assimilation and cellular pigment levels. This is in accord with the results of the laboratory study of Fu et al. (2007), in which most of the effect observed in Synechococcus growth was caused by high temperature rather than increased $\mathrm{pCO}_{2}$. These observations suggest that, unlike Trichodesmium, which is limited by inorganic carbon at low $\mathrm{pCO}_{2}$, single cell cyanobacteria are not C-limited at low $\mathrm{pCO}_{2}$.

\section{CONCLUSIONS}

According to the results of the present field study, the only consistent and significant effect of decreasing $\mathrm{pH}$ on the cyanobacterial phytoplankton at BATS was an increase in $\mathrm{N}_{2-}$ and C-fixation by Trichodesmium. This increase, which was seen in isolated T. thiebautii colonies in the field, is similar to what has been observed in several studies with pure cultures of T. erythreum IMS101 (e.g. Barcelos e Ramos et al. 2007, Hutchins et al. 2007). The implication is that rising $\mathrm{pCO}_{2}$ in surface seawater could lead to a substantial augmentation of $\mathrm{N}_{2}$-fixation rates by Trichodesmium and thus an increasing input of fixed $\mathrm{N}$ into marine ecosystems where this organism thrives. A major caveat is that, like most field measurements, our results were obtained under conditions of excess $\mathrm{P}$ and $\mathrm{Fe}, 2$ nutrients that often limit the growth of Trichodesmium in the ocean (Paerl et al. 1994, Lenes et al. 2001, Sañudo-Wilhelmy et al. 2001, Achilles et al. 2005). Stratification will likely only increase in a future $\mathrm{pCO}_{2}$-enriched ocean, thus reducing vertical nutrient inputs in the subtropical and tropical gyres where Trichodesmium is most important (Sarmiento et al. 2004). Hutchins et al. (2007) showed that under P limitation, Trichodesmium maintained near maximum growth rates due a reduction in cellular P quota, likely through substitution of sulfolipids for phospholipids (Van Mooy et al. 2009), thus countering potential reductions in growth rate associated with increased nutrient limitation associated with increased stratification (e.g. Rost et al. 2008).

Bulk communities dominated by Synechococcus and Prochlorococcus, while showing a short term $\mathrm{pH}$ response (depression of $\mathrm{C}$-fixation at high $\mathrm{pH}$ ), rapidly acclimate and up-regulate photosynthetic capacity such that $\mathrm{pH}$-dependent responses are no longer evident after 1 to $3 \mathrm{~d}$, the temporal resolution of these 
experiments. Our observations of small and non-significant effects of $\mathrm{pH}$ on Prochlorococcus and Synechococcus growth and physiological parameters are also in accord with the results of laboratory experiments with pure cultures (Fu et al. 2007) and further highlight the differences in response of similar phytoplankton to the same change in an environmental parameter. While a number of studies of phytoplankton response to increased $\mathrm{pCO}_{2}$ have reported a variety of potentially significant responses (reviews by Fabry 2008, Hutchins et al. 2009), it may be important to remember that many experiments in which no measurable effect of increasing $\mathrm{pCO}_{2}$ were detected have probably not been published. In the field of ocean acidification, all responses are important to understand how future autotrophs will respond to these environmental changes.

Acknowledgements. We thank the Captain and crew of the RV 'Atlantic Explorer' for their assistance in conducting this research and S. Goldberg for flow cytometric analyses. This work was supported by NSF funding to F.M.M.M. and NSF award OCE-0752161 to M.W.L. We thank the National Science Foundation Chemical and Biological Oceanography Programs for continued support of the BATS program (OCE0752366). This is BIOS contribution No. 2021.

\section{LITERATURE CITED}

Achilles KM, Lipschultz F, Sedwick P, Luther G, Church T (2005) Importance of iron to Trichodesmium colonies in the western North Atlantic. ASLO 2005 Aquatic Sciences Conference Abstract Book 4, Feb 20-25, Salt Lake City

Badger MR, Price GD, Long BM, Woodger FJ (2006) The environmental plasticity and ecological genomics of the cyanobacterial $\mathrm{CO}_{2}$ concentrating mechanism. J Exp Bot 57:249-265

Barcelos e Ramos J, Biswas H, Schulz KG, La Roche J, Riebesell U (2007) Effect of rising atmospheric carbon dioxide on the marine nitrogen fixer Trichodesmium. Glob Biogeochem Cycles 21, GB2028, doi:10.1029/2006 GB002898

Bates NR (2007) Interannual variability of the oceanic $\mathrm{CO}_{2}$ sink in the subtropical gyre of the North Atlantic Ocean over the last two decades. J Geophys Res 112, C09013, doi:10.1029/2006JC003759

Bates NR, Michaels AF, Knap AH (1996) Seasonal and interannual variability of oceanic carbon dioxide species at the US JGOFS Bermuda Atlantic time-series study (BATS) site. Deep-Sea Res II 43:347-383

Beardall J, Stojkovic S, Larsen SH (2009) Living in a high $\mathrm{CO}_{2}$ world: impacts of global climate change on marine phytoplankton. Plant Ecol Divers 2:191-205

> Boyd PW, Doney SC (2002) Modelling regional responses by marine pelagic ecosystems to global climate change. Geophys Res Lett 29, 1806, doi:10.1029/2001GL014130

Capone DG, Burns JA, Montoya JP, Subramaniam A and others (2005) Nitrogen fixation by Trichodesmium spp.: an important source of new nitrogen to the tropical and subtropical North Atlantic Ocean. Glob Biogeochem Cycles 19, GB2024, doi:10.1029/2004GB002331

Czerny J, Barcelos e Ramos J, Riebesell U (2009) Influence of elevated $\mathrm{CO}_{2}$ concentrations on cell division and nitrogen fixation rates in the bloom-forming cyanobacterium Nodularia spumigena. Biogeosciences 6: 1865-1875

Engel A, Zondervan I, Aerts K, Beaufort L and others (2005) Testing the direct effect of $\mathrm{CO}_{2}$ concentration on a bloom of the coccolithophorid Emiliania huxleyi in mesocosm experiments. Limnol Oceanogr 50:493-507

Fabry VJ (2008) Marine calcifiers in a high- $\mathrm{CO}_{2}$ ocean. Science 320:1020-1022

Feng Y, Hare CE, Leblanc K, Rose JM and others (2009) Effects of increased $\mathrm{pCO}_{2}$ and temperature on the North Atlantic Spring Bloom. I. The phytoplankton community and biogeochemical response. Mar Ecol Prog Ser 388: $13-25$

Fu FX, Warner ME, Zhang Y, Feng Y, Hutchins DA (2007) Effects of increased temperature and $\mathrm{CO}_{2}$ on photosynthesis, growth, and elemental ratios in marine Synechococcus and Prochlorococcus (Cyanobacteria). J Phycol 43:485-496

Fu FX, Mulholland MR, Carcia NS, Beck A and others (2008) Interactions between changing $\mathrm{pCO}_{2}, \mathrm{~N}_{2}$ fixation and $\mathrm{Fe}$ limitation in the marine unicellular cyanobacteria Crocosphaera. Limnol Oceanogr 53:2472-2484

Gattuso JP, Gao K, Lee K, Rost B, Schulz KG (2010) Approaches and tools to manipulate the carbonate chemistry. In: Riebesell U, Fabry VJ, Hansson L, Gattuso JP (eds) Guide to best practices for ocean acidification research and data reporting. Publications Office of the European Union, Luxembourg

- Hare CE, Leblanc K, DiTullio GR, Kudela RM and others (2007) Consequences of increased temperature and $\mathrm{CO}_{2}$ for phytoplankton community structure in the Bering Sea. Mar Ecol Prog Ser 352:9-16

> Hopkinson BM, Xu Y, Shi DL, McGinn PJ, Morel FMM (2010) The effect of $\mathrm{CO}_{2}$ on the photosynthetic physiology of phytoplankton in the Gulf of Alaska. Limnol Oceanogr 55:2011-2024

Hutchins DA, Fu FX, Zhang Y, Warner ME and others (2007) $\mathrm{CO}_{2}$ control of Trichodesmium $\mathrm{N}_{2}$ fixation, photosynthesis, growth rates, and elemental ratios: implications for past, present, and future ocean biogeochemistry. Limnol Oceanogr 52:1293-1304

Hutchins DA, Mulholland MR, Fu FX (2009) Nutrient cycles and marine microbes in a $\mathrm{CO}_{2}$-enriched ocean. Oceanography (Wash DC) 22:128-145

> Kim JM, Lee K, Shin K, Kang JH and others (2006) The effect of seawater $\mathrm{CO}_{2}$ concentrations on growth of a natural phytoplankton assemblage in a controlled mesocosm experiment. Limnol Oceanogr 51:1629-1636

Kim JM, Lee K, Shin K, Yang EJ, Engel A, Karl DM, Kim HC (2011) Shifts in biogenic carbon flow from particulate to dissolved forms under high carbon dioxide and warm ocean conditions. Geophys Res Lett 38, L08612, doi:10. 1029/2011GL047346

Kranz SA, Sultemeyer D, Richter KU, Rost B (2009) Carbon acquisition by Trichodesmium: the effect of $\mathrm{pCO}_{2}$ and diurnal changes. Limnol Oceanogr 54:548-559

> Kranz SA, Levitan O, Richter KU, Prášil O, Berman-Frank I, Rost B (2010) Combined effects of $\mathrm{CO}_{2}$ and light on the $\mathrm{N}_{2}$-fixing cyanobacterium Trichodesmium IMS101: physiological responses. Plant Physiol 154:334-345 
Lenes JM, Darrow BP, Cattrall C, Heil CA and others (2001) Iron fertilization and the Trichodesmium response on the West Florida shelf. Limnol Oceanogr 46:1261-1277

Levitan O, Rosenberg G, Setlik I, Setlikova E and others (2007) Elevated $\mathrm{CO}_{2}$ enhances nitrogen fixation and growth in the marine cyanobacterium Trichodesmium. Glob Change Biol 13:531-538

> Levitan O, Brown C, Sudhaus S, Campbell DA, LaRoche J, Berman-Frank I (2010) Regulation of nitrogen metabolism in the marine diazotroph Trichodesmium IMS101 under varying temperatures and atmospheric $\mathrm{CO}_{2}$ concentrations. Environ Microbiol 12:1899-1912

Lomas MW, Steinberg DK, Dickey T, Carlson CA, Nelson NB, Condon RH, Bates NR (2010) Increased ocean carbon export in the Sargasso Sea is countered by its enhanced mesopelagic attenuation. Biogeosciences 7:57-70

> Lueker TJ, Dickson AG, Keeling CD (2000) Ocean $\mathrm{pCO}_{2}$ calculated from dissolved inorganic carbon, alkalinity and equations for $\mathrm{K} 1$ and $\mathrm{K} 2$ : validation based on laboratory measurements of $\mathrm{CO}_{2}$ in gas and seawater at equilibrium. Mar Chem 70:105-119

Montoya JP, Voss M, Kahler P, Capone DG (1996) A simple, high-precision, high-sensitivity tracer assay for $\mathrm{N}_{2}$ fixation. Appl Environ Microbiol 62:986-993

Orcutt KM, Lipschultz F, Gundersen K, Arimoto R, Michaels AF, Knap AH, Gallon JR (2001) A seasonal study of the significance of $\mathrm{N}_{2}$ fixation by Trichodesmium spp. at the Bermuda Atlantic Time-series Study (BATS) site. DeepSea Res II 48:1583-1608

Paerl HW, Prufert-Bebout LE, Guo C (1994) Iron stimulated $\mathrm{N}_{2}$ fixation and growth in natural and cultured populations of the planktonic marine cyanobacteria Trichodesmium spp. Appl Environ Microbiol 60:1044-1047

Parsons TR, Maita Y, Lalli CM (1984) A manual of chemical and biological methods for seawater analysis. Pergamon, Oxford

Partensky F, Hess WR, Vaulot D (1999) Prochlorococcus, a marine photosynthetic prokaryote of global significance. Microbiol Mol Biol Rev 63:106-127

> Paulino AI, Egge JK, Larsen A (2008) Effects of increased atmospheric $\mathrm{CO}_{2}$ on small and intermediate sized osmotrophs during a nutrient induced phytoplankton bloom. Biogeosciences 5:739-748

Riebesell U, Schulz KG, Bellerby RGJ, Botros M and others (2007) Enhanced biological carbon consumption in a high $\mathrm{CO}_{2}$ ocean. Nature 450:545-548

Rose JM, Feng Y, Gobler CJ, Gutierrez R, Hare CE, Leblanc K, Hutchins DA (2009) Effects of increased pCO2 and temperature on the North Atlantic spring bloom. II. Microzooplankton abundance and grazing. Mar Ecol Prog Ser 388:27-40

Rost B, Zondervan I, Wolf-Gladrow D (2008) Sensitivity of phytoplankton to future changes in ocean carbonate chemistry: current knowledge, contradictions and research directions. Mar Ecol Prog Ser 373:227-237
Sañudo-Wilhelmy SA, Kustka AB, Gobler CJ, Hutchins DA and others (2001) Phosphorus limitation of nitrogen fixation by Trichodesmium in the central Atlantic Ocean. Nature 411:66-69

Sarmiento JL, Slater RD, Barber RT, Bopp L and others (2004) Response of ocean ecosystems to climate warming. Glob Biogeochem Cycles 18, GB3003, doi:10.1029/ 2003GB002134

Shi D, Xu Y, Morel FMM (2009) Effects of the pH/pCO $\mathrm{pCon}_{2}$ trol method on medium chemistry and phytoplankton growth. Biogeosciences 6:1199-1207

> Siegel DA, Westberry TK, O'Brien MC, Nelson NB and others (2001) Bio-optical modeling of primary production on regional scales: the Bermuda BioOptics project. DeepSea Res II 48:1865-1896

Sieracki ME, Verity PG, Stoecker DK (1993) Plankton community response to sequential silicate and nitrate depletion during the 1989 North Atlantic spring bloom. DeepSea Res II 40:213-226

> Slawyk G, Collos Y, Auclair JC (1977) The use of ${ }^{13} \mathrm{C}$ and ${ }^{15} \mathrm{~N}$ isotopes for the simultaneous measurement of carbon and nitrogen turnover rates in marine phytoplankton. Limnol Oceanogr 22:925-932

Sommer U, Aberle N, Engel A, Hansen T and others (2007) An indoor mesocosm system to study the effect of climate change on the late spring and summer succession of Baltic Sea phyto- and zooplankton. Oecologia 150: 655-667

Steinberg DK, Carlson CA, Bates NR, Johnson RJ, Michaels AF, Knap AH (2001) Overview of the US JGOFS Bermuda Atlantic Time-series Study (BATS): a decadescale look at ocean biology and biogeochemistry. DeepSea Res II 48:1405-1447

Tang DG, Morel FMM (2006) Distinguishing between cellular and Fe-oxide-associated trace elements in phytoplankton. Mar Chem 98:18-30

Tortell PD, DiTullio GR, Sigman DM, Morel FMM (2002) $\mathrm{CO}_{2}$ effects on taxonomic composition and nutrient utilization in an Equatorial Pacific phytoplankton assemblage. Mar Ecol Prog Ser 236:37-43

Tortell PD, Payne CD, Li YH, Trimborn S and others (2008) $\mathrm{CO}_{2}$ sensitivity of Southern Ocean phytoplankton. Geophys Res Lett 35, L04605, doi:10.1029/2007GL032583

Van Mooy BAS, Fredricks HF, Pedler BE, Dyhrman ST and others (2009) Phytoplankton in the ocean use non-phosphorus lipids in response to phosphorus scarcity. Nature 458:69-72

Yoshimura T, Nishioka J, Suzuki K, Hattori H, Kiyosawa H, Watanabe YW (2010) Impacts of elevated $\mathrm{CO}_{2}$ on organic carbon dynamics in nutrient depleted Okhotsk Sea surface waters. J Exp Mar Biol Ecol 395:191-198

Zhang HM, Byrne RH (1996) Spectrophotometric pH measurements of surface seawater at in-situ conditions: absorbance and protonation behavior of thymol blue. Mar Chem 52:17-25

Submitted: September 27, 2011; Accepted: May 15, 2012 Proofs received from author(s): June 22, 2012
Editorial responsibility: Hugh MacIntyre,

Halifax, Nova Scotia, Canada 